\title{
THE ROMAN ARMY DURING THE REGAL PERIOD
}

\author{
Dana DINU \\ University of Craiova, Romania \\ dinudana9@yahoo.com
}

\begin{abstract}
The intention of this article is to give a brief overview of how the military power was organised in Rome during the regal period. There is little information about the military organisation of the Romans between 753 and 509 BC. However, some written historical sources have enabled us to reconstruct some aspects of the military life in early Rome. The Indo-European studies and the comparative mythology of the Indo-European peoples also help to understand how the warrior function was valued in early Roman society. Like the other Indo-European peoples, the Romans structured their society in a system reflecting the ideology of the three functions represented, according to G. Dumézil, by the priests, warriors and herdsmen-cultivators. The same conception can be found at the theological level, within the triad Jupiter, Mars, Quirinus, the most important gods of Rome. Romulus, the founder of Rome, is the son of the god Mars, thereby consecrating the predominance of the warlike function within the trifunctional system. The army has always been the main instrument that assured the defence of Rome, but especially the expansion and preservation of its power over the conquered territories.
\end{abstract}

Keywords: Regal Rome, Roman army, military organising, Romulus, Servius Tullius.

\section{Introduction}

There is little known about the military organisation and combat techniques of the Romans before Servius Tullius (578-534 $\mathrm{BC})$ and even less from before the foundation of Rome (754/3 BC). Regarding the prehistoric times, we can extract some conjectural information from the Latin historiography or other types of texts that use sources no longer accessible today, as well as from various traditions. For this period, the archaeology has an important contribution due to the findings - few concerning this age, but therefore even more valuable - which complement, confirm or deny the uncertain information.

However, looking back over the centuries, it is not difficult to see that the army created the Roman power, imperium, and that the power, imperium, created the Roman army. The two mutually strengthened each other.
All the conquests against the formidable enemies, mostly those against the Carthaginians, created the need to introduce innovations in order to increase the organisation, efficiency, to improve logistics, strategies, tactics and discipline of the army, and inspire the fighters to adopt the winner mentality. A few elements of the primordia of Roman history, in Livy's words, are found in the oldest remnant texts by Roman historians. Q. Fabius Pictor, the first Latin historian, who wrote in Greek a history of Rome from its very foundation, mentions the Trojan Aeneas as the founder of the Roman people [1]. In other words, the origin of the Roman people is related to an event which took place in the Eastern Mediterranean, namely the fall of Troy. The Trojan migration to the Italian peninsula might have occurred after 1184 BC, according to Eratosthenes, more than four 
hundred years before Rome was founded. This long period of time saw the gradual creation of what later, after the founding of Rome, was to become, the Roman people.

Aeneas's mission was to find himself a new homeland [2]. The natives of these lands or the aborigines were the Latins led by Latinus. Apart from them, there was the Sabine people. But on the arrival of the Trojans in Italy, there was already the Greek migration of the Arcadians led by king Evander. The Trojans, the Greeks, the Latins and the Sabines are Indo-European peoples. Another ethnic element pre-existing the arrival of the Trojans are the Etruscans, a people who also came to Italy from Asia Minor after an earlier migration, but of nonIndo-European origin. The primordial synoikismos of these five tribes, under the leadership of Aeneas and with the decisive contribution of the Latins, whose ethnonym prevailed, laid the foundation of the Roman people. Roman historians generally accepted this vulgate, but to many of the modern ones it seemed merely fiction, until the archaeological excavations of the last decades have come to confirm some of these traditions. The process of welding these five ethnic elements together was not a peaceful or a linear one. Only Latinus, the King of Latium, entered into an alliance with Trojans by giving his daughter Lavinia into marriage to Aeneas, who succeeded him to the throne thus_creating a dynasty of rulers of Latium, which will continue until Romulus and Remus. The genesis of the Roman people relies strongly on the Indo-European heritage, due to the four of the five tribes that shaped it. Because of their warrior spirit, constantly put to the test throughout their early history, the Romans became in the course of their existence not only a resilient nation, but in the end a nation of world rulers. The Etruscans played an important role by adding to the Latin heritage essential elements of their technology, civilization, and culture.
2. Military organisation before the founding of Rome. We do not have direct information on the military organisation, weaponry or fighting technique between the arrival of Aeneas in Italy until the founding of Rome, which means four hundred years of prehistory. We do not dispose of relevant data on the battles that took place during this period, but we can assume that in the Bronze Age battles were of a small scale compared with the great wars of Rome, that they were fought at relatively small distances from the cities and that the forces engaged on both sides were comparable in terms of number and military endorsement but on the gaining side were those with better mobilization, better organisation and more determination. Plutarch gives us in the Life of Romulus (VIII, 5-6) some information about a form of military organisation at the end of the prehistoric period, very shortly before the foundation of Rome. He writes about the moment when the twins Romulus and Remus restored their grandfather Numitor to the throne of the city of Alba. On this occasion, the two brothers organise the crowd of disgruntled citizens against the usurper Amulius in formations of one hundred men each, called manipuli. This is the period when all male citizens indiscriminately serve in the army. Plutarch also mentions that his information sources are the Greek historian Diocles of Peparethus (IV-III BC) and the Latin historian Q. Fabius Pictor, who in his turn used as a source the same Diocles. Hence the earliest reference we have is dated about four hundred years after this event.

\section{Evolution of the military organisation} of Rome. According to Marquardt [3], the Roman military organisation went through three periods, defined by important historical events. The first period begins with the foundation of Rome and ends after the social wars, the second period is that of the mercenary wars and the third period is that of the permanent army. The first of these periods is not a homogeneous one, but 
happens in three phases: the first one starts with the foundation of Rome and lasts until Servius Tullius (758-534 BC), the second stretches from Servius Tullius to Camillus (534-365 BC), and the third from Camille to Marius and the end of the social wars, known as bellum sociale, the wars with socii, the allies of Rome (365-88 BC).

\subsection{The Roman army from Romulus to} Servius Tullius. According to Dionysius of Halicarnassus $(2,13)$ and Plutarch $(12,13$, 1-3), Romulus, the founder king of Rome, created by recruitment, legio, among the patricians, the first rigorously organized army, headed by himself, as their king, rex. This army numbered 3,000 infantry and 300 knights. The warriors were equally drafted by affiliation to one of Rome's three tribes, tribus, based on ethnicity. The first tribe in chronological order and of its importance was that of the Latins, also called Ramnes. They then annexed the Sabines and their tribe was named Tities, after their king Titus Tatius. The Etruscans formed the third tribe, Luceres. The military tribes therefore corresponded to these ethnic tribes. This information can be found in Servius, based on Varro's information: tres equitum numero turmae: rem Romanae militiae suo inscrit carmini. Nam constat, primo tres partes fuisse populi Romani, unam Titiensium, alteram Ramnetum, tertiam Lucerum. Sic autem in tres partes divisum fuisse populum constat, ut etiam, qui praeerant singulis partibus, tribuni dicerentur (ad Aen. 5, 560). The military tribes were each headed by a tribunus militum. The term miles - soldier, warrior -, in the plural milites, is seen as a derivative of mille, one thousand, created by analogy with eques - equites, pedes - pedites, the names of the military divisions of knights and infantry. Varro explains the relationship between miles and mille in the following way: Milites, quod trium milium primo legio fiebat ac singulae tribus Titiensium Ramnium Lucerum milia militum mittebant $(5,89)$. For modern linguists, the etymology of this term is not very clear. Each tribe was divided into ten curiae, formations of one hundred warriors, called centuriae (centuviria , viri $=$ warriors) or manipuli, led by an officer called curio. The subdivision of a curia was called decuria (decu-viria) because it consisted of 10 viri and stood for the tenth part of a centuria, under the leadership of a decurio. The cavalry corps, called equites or celeres, sometimes flexuntes/flexumines or trossuli, also served as a personal guard to Romulus. There is a confusion arising from the interpretation of a passage of Livy in which he seems to say that there were two categories of knights: three hundred equites plus the king's personal guard, celeres. In reality in this period of time, he refers to the same battle group by different names. Festus later clarifies the matter: Celeres antiqui dixerunt quos nunc equites dicimus ... qui primitus electi fuerunt ex singulis curiis deni ideoque omnes trecenti fuere [4]. The Knights were organized in three centuries, centuriae, each of them with a tribunus celerum in command. The cavalry had as subdivision 10 squadrons of 30 fighters, called turmae, in turn divided into three formations of 10 horsemen called decuriae, headed by a decurio. The king appointed a cavalry chief, magister equitum, but the cavalry was at his disposal. According to some interpretations, the knights wore a gold ring as a distinctive sign of their emerging Knights' class, located on the social scale directly under the Patricians' class and in no relation to the plebs. In contrast with the infantry, the knights were in permanent military service, even in times of peace. As for the period in which the cavalry was created, historical information differs. Dionysius of Halicarnassus says that Romulus formed this military body right after the Senate was created $(13,1)$. According to Livy and Plutarch, on the other hand, this seems to have happened after the creation of the union of the three ethnic tribes and the combined rule of Titus Tatius and Romulus at the head of the reign. This structure of the primitive Roman army did not remain unchanged, 
under the following kings the number of knight centuriae first increased at six, eventually to reach 18 during Servius Tullius. The army consisting of the two core bodies could be enlarged with three centuriae by admitting minores gentes. These troops were made up of the so-called adscripticii. The Patricians' clients, clientes, could also be enroled in the army, but only as lightly armed troops, called velites or arquites. Romulus was a warrior king and had many battles with neighbouring cities. The battles he waged were initially reactions to the attacks of neighbouring cities in Latium and not necessarily expansionary wars, but they led to the expansion of Roman power. In the first period after it was founded, Rome's position was rather defensive or reactive. The first battle of this kind was with Caenina, a city in Latium of yet unknown location in about $749 \mathrm{BC}$. The outcome of the war was decided by duel or monomahia between the two rival commanders Romulus and Acron. Romulus distinguished himself in this act of military bravery inspired by Homer's epic poems, he defeated his opponent and took his weapons as a trophy. This victory earned him a hero's reputation and was celebrated in triumph, the first one in the long row to follow. This was, in the account of Dionysius of Halicarnassus, the first triumphal ceremony in Rome. During the ceremony, Romulus would have paraded in a four-horse-drawn chariot, the same Dionysius describes, but Plutarch, knowing of the existence of statues in Rome which represented Romulus standing and bearing his trophy, says that the first triumphal chariot appears much later and was granted to the first Etruscan king Tarquinius Priscus. Crustumerium, Antemnae and Etruscan city Fidenae on the left bank of the Tiber are more cities of Latium conquered by Romulus. The rising power of Rome caused concern across the Tiber, in the Etruscan city of Veii, with its outpost Fidenae. Therefore, its inhabitants made incursions into territories controlled by Rome, but were defeated on the battlefield.
Romulus, although he had reached the gates of the city of Veii, did not have enough troops and equipment to besiege and destroy it, as he intended. The inhabitants of the conquered cities were incorporated into the tribes and curiae of Rome, thus becoming Roman citizens. As a result, they fell under the duty of military service. Thus, after the conquest of the cities of Caenina and Antemnae, the armed power of Rome increased by 3000 soldiers, according to Dionysius of Halicarnassus $(2,35,6)$. The battle for Veii was Romulus' last. Until Servius Tullius, the changes that occurred in the military organisation under the kings who succeeded Romulus are not known. The recruitment base for military service was formed by the citizenry. There is reason to believe that, in Rome's primitive age, all citizens fell under military duty. But of course, children, elderly, those unable to wear weapons for various reasons, and those who declined on religious or moral grounds, were exempt from service. Roman citizenship came with the duty of military service. But during Romulus' reign, fighting in the city's army was considered rather a privilege. However, Roman citizens were not only the patricians, but also the plebeians, who had a military potential that the city could no longer ignore, as wars became more frequent and increasingly difficult. In time it became necessary to broaden the recruitment base. The patrician city, which restricted the civil and military rights to only some members of the social body, had to give way to the patricioplebeian city by accepting the plebeian contribution to the military effort of the city.

\subsection{Servius Tullius' Reforms}

From 616 BC, for a little over a hundred years, three Etruscan kings ruled over Rome. Their contribution to the development of Rome can hardly be overlooked, since at that time the Etruscans mastered the advanced iron technology and had a superior civilization to that of the Romans in all respects. The sixth Roman king and the second of the Etruscan kings was Servius 
Tullius, and at the same time the penultimate king of Rome. He is credited with the reform named Servian, after his own name. Roman society and institutions are now founded on a new constitution of Greek inspiration, emulating the reforms applied in Athens by Solon. Citizens are classified by wealth or census, which gives rise to the censitar classes in which the ethnic or genetic criterion is replaced by a criterion allowing greater social mobility. It was a more objective, more "democratic" criterion that gave plebeians political rights conditioned by military and fiscal obligations to the state, because one of the aims of the reform was to create a clear and relatively fair taxation system. The citizens divided in groups of one hundred, id est in the centuries of each class as set up by census, formed the centuriate assembly, comitia centuriata, which had legislative, electoral, or judicial powers exerted by citizens through voting. The power of the vote of a member of the assembly was directly proportional to his position within the economic and social hierarchy as defined in the Servian constitution. This system motivates a larger number of citizens to get involved in the political affairs of the state and in its defense, thus creating a stronger social cohesion. The application of the Servian constitution gave rise to six classes, five in reality because the knights were considered outside the classes and above them. The classes concerned those who were recruited for infantry, ranked in decreasing order of the census, as follows: the knights' class or the equestrian class included owners of a fortune of at least 1 million asses, making up 18 centuries, of which 12 included men aged between 17 and 45 named iuniores and the remaining 6 the seniores, those aged between 46 and 60 years. These age groups were applied to the rest of the census classes, with the difference that, within each of them the centuries were equally divided between iuniores and seniores. The next classes were infantry: the first class, with a census of one hundred thousand asses, had 80 centuries, the second class, with a census of 75,000 asses, had 20 centuries, the third one had a census of 50,000 and 20 centuries, the fourth had a census of 25,000 asses, and equally 20 centuries, and the last infantry class was the least wealthy, with a census of 11,000 asses, and 30 centuries. In total, 188 centuries. Besides them there were 5 more centuries which fell outside the class division or supernumerarii: 2 were made up of engineer troops, 2 of trumpeters, cornicines and tubicines, and 1 of the capite censi or proletarii, with a fortune of less than 11,000 asses. The total number of centuries was 193. In terms of actual military organisation, we see the adoption of a mixed model, Etruscan-Roman, which in turn was inspired by the Greek or Macedonian hoplite phalanx, as Livy says: et quod antea phalanges similes Macedonicis, hoc postea manipulatim structa acies coepit esse (VIII, 8). The hoplite is the heavily armed infantryman. His equipment consisted of defense weapons: helmet, greaves, ocreae, breastplate, lorica, and shield, clipeus, of circular or square shape, and attack weapons, spear, hasta, and sword, gladium. The hoplite phalanx acted in solidarity, the fighters stood shoulder to shoulder in very tight rows. The number of rows could vary between eight and twelve. According to other sources (Livy I, 43), there were three to six rows. Within the phalanx there were various ranks. The first two rows deployed fully equipped first class citizens. They were called principes. In the next two rows came the infantrymen belonging to the second class. They did not wear a breastplate, but they were protected by a clipeus, and carried the same kind of equipment. They were called hastati. The fifth and sixth rows were filled by the third-class warriors. They did not wear greaves. They were called triarii. Dionysius of Halicarnassus and Livy give contradicting descriptions of the role of the fourth class, in the sense that first one says they were part of the heavy-armed infantry, and the other that they were carrying only the spear, hasta, and the lance, verutum. The 
explanation might be that they were deployed in either role, as the situation required. Most likely, they were not part of the phalanx, as neither was the fifth class. They formed the light troops and were called rorarii. Their mission was to act at the beginning of the battle by launching slingshots and spears and hurling stones at the enemy camp and then retreating. The Servian legions were recruited from the regional tribes, which implied their obligation to supply their assigned contingents. In the Servian army, the infantry troops played the most important role. The cavalry is moved to the sides of the phalanx and intervenes in certain situations. Thus, although the number of knights is much higher than at the time of Romulus, the position of the knights begins to lose its military content and acquires an increasing social and political significance.

4. Conclusions. At the beginning of regal period, the Romans already had a long warfare experience. They built themselves as a people in constant competition with the neighbouring nations, which they managed to dominate, to integrate into their own universe, and eventually to assimilate them until their identity was irreversibly changed. The army was a major part in this process. The reforms attributed to Servius Tullius followed the transformations that have occurred in Roman society and had a positive role in increasing its military capacity.

\section{References}

[1] Historicorum Romanorum Fragmenta, Hermann Peter (ed), Lipsiae, Teubner, 1883, p. 8.

[2] Strechie, M., Oameni politici ai Romei antice (Lideri, institutții si mentalități), Craiova, Editura Universitaria Craiova, 2008, pp. 9-22.

[3] Marquardt, Joachim, De l'organisation militaire chez les romains, Traduit de l'allemand par J. Brissaud, Paris, Ernest Thorin Éditeurs, 1891, p. 2-3.

[4] Sexti Pompei Festi De verborum significatu, edidit W. M. Lindsay, Stutgardiae et Lispsiae, Teubner, 1997, sub v. celeres, p. 48. 